\title{
Enzyme-Responsive Snap-Top Covered Silica Nanocontainers
}

\author{
Kaushik Patel, ${ }^{\dagger}$ Sarah Angelos, ${ }^{\dagger}$ William R. Dichtel, ${ }^{\dagger, \ddagger}$ Ali Coskun, Ying-Wei Yang, ${ }^{\dagger}$ \\ Jeffrey I. Zink, ${ }^{\dagger}$ J. Fraser Stoddart ${ }^{\dagger *}$ \\ ${ }^{\dagger}$ California NanoSystems Institute and Department of Chemistry and Biochemistry, \\ University of California, Los Angeles, 405 Hilgard Avenue, Los Angeles, CA 90095, USA \\ ${ }^{*}$ Division of Chemistry and Chemical Engineering, California Institute of Technology, \\ 1200 East California Boulevard, Pasadena, CA 91125, USA
}

\section{Supporting Information}

\begin{tabular}{|c|}
\hline Correspondence Addresses \\
Professor J Fraser Stoddart \\
California NanoSystems Institute and \\
Department of Chemistry and Biochemistry \\
University of California, Los Angeles \\
405 Hilgard Avenue \\
Los Angeles, CA 90095-1569 (USA) \\
Tel: (+1)-310-206-7078 \\
Fax: (+1)-310-206-1843 \\
Email: $\underline{\text { stoddart@chem.ucla.edu }}$ \\
Professor Jeffrey I Zink \\
California NanoSystems Institute and \\
Department of Chemistry and Biochemistry \\
University of California, Los Angeles \\
405 Hilgard Avenue \\
Los Angeles, CA 90095-1569 (USA) \\
Tel: (+1)-310-825-1001 \\
Fax: (+1)-310-206-4038 \\
Email: zink@.chem.ucla.edu \\
\hline
\end{tabular}


General Methods. All reagents were purchased from commercial suppliers (Aldrich or Fisher) and used without purification. Column chromatography was performed on silica gel $60 \mathrm{~F}$ (Merck 9385, 0.040-0.063 nm). Nuclear magnetic resonance (NMR) spectra were recorded on a Bruker Avance $500\left({ }^{1} \mathrm{H}: 500 \mathrm{MHz} ;{ }^{13} \mathrm{C}: 126 \mathrm{MHz}\right)$ spectrometer. Chemical shifts are reported as parts per million (ppm) using $\mathrm{CDCl}_{3}$ as the reference solvent, for both ${ }^{1} \mathrm{H}$ and ${ }^{13} \mathrm{C}$ NMR spectroscopies, unless otherwise indicated. SEM images were collected on a JEOL SM-71010 (fine powder profile). Au coating of the particles used for imaging was carried out by sputtering for $1 \mathrm{~min}$ (Hummer 6.2, Anatech LTD, plasma discharge current $=15 \mathrm{~mA}$ at $70 \mathrm{mTorr}$ ). IR spectra were collected on a Perkin-Elmer FT-IR Paragon 500 spectrometer using $\mathrm{KBr}$ pellets. UV-vis spectra were collected on a Cary $5000 \mathrm{UV}$-vis-NIR spectrophotometer. The controlled release profiles were obtained via luminescence spectroscopy using an Acton SpectraPro 2300i CCD, and a coherent Argon Innova 90C-5 excitation laser.

Scheme S1. Synthesis of Azido-Toluenesulfonate Derivative 1.

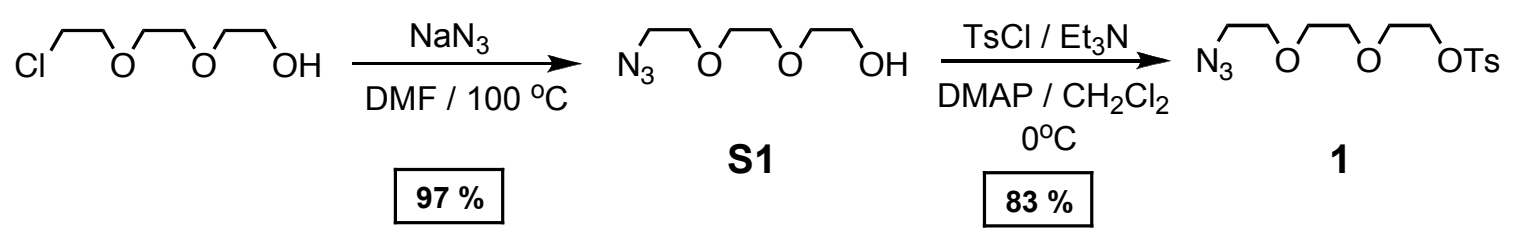

2-(2-(2-Azidoethoxy)ethoxy)ethanol (S1): ${ }^{\mathrm{S} 1}$ A mixture of 2-(2-(2-chloroethoxy)ethoxy)ethanol $(5.0 \mathrm{~g}, 30 \mathrm{mmol})$ and $\mathrm{NaN}_{3}(3.0 \mathrm{~g}, 45 \mathrm{mmol})$ in DMF $(100 \mathrm{ml})$ was stirred at $100^{\circ} \mathrm{C}$ for $48 \mathrm{~h}$. The mixture was then cooled to RT, filtered and the solvent was removed under vacuum to afford the product S1 (5.1 g, $97 \%$ ) as a colorless oil. Characterization was in agreement with the literature. ${ }^{1}$

2-(2-(2-Azidoethoxy)ethoxy)ethyltoluenesulfonate (1): ${ }^{\mathrm{S} 2} \mathrm{~A}$ mixture of 2-(2-(2-azidoethoxy) ethoxy)ethanol (S1) $(1.0 \mathrm{~g}, 5.7 \mathrm{mmol})$, DMAP $(80 \mathrm{mg}, 0.66 \mathrm{mmol})$ and $\mathrm{Et}_{3} \mathrm{~N}(4.0 \mathrm{~g}, 40 \mathrm{mmol})$ was dissolved in $\mathrm{CH}_{2} \mathrm{Cl}_{2}(150 \mathrm{ml})$ and cooled down to $0^{\circ} \mathrm{C}$. A solution of $p$-toluenesulfonyl chloride $(4.77 \mathrm{~g}, 25 \mathrm{mmol})$ in $\mathrm{CH}_{2} \mathrm{Cl}_{2}(50 \mathrm{ml})$ was added dropwise to this mixture. The solution was allowed to warm up to RT before being stirred for $18 \mathrm{~h}$. The progress of the reaction was monitored by thin layer chromatography and the solvent removed under vacuum following disappearance of the starting material. The mixture was then passed through a silica plug with EtOAc as the eluent. The solution was then washed with $\mathrm{H}_{2} \mathrm{O}(2 \times 50 \mathrm{~mL})$ and brine $(1 \times 50 \mathrm{~mL})$ and the solvent evaporated to provide $1(1.2 \mathrm{~g}, 83 \%)$ as a pale orange oil. Characterization was in agreement with the literature. ${ }^{2} \mathrm{HRMS}$ (FAB): Calcd for $\mathrm{C}_{13} \mathrm{H}_{20} \mathrm{SO}_{5} \mathrm{~N}_{3} \mathrm{~m} / z=330.1124$. Found $m / z$ $=330.1134$.

Scheme S2. Synthesis of Adamantyl-Ester Derivative 2a.
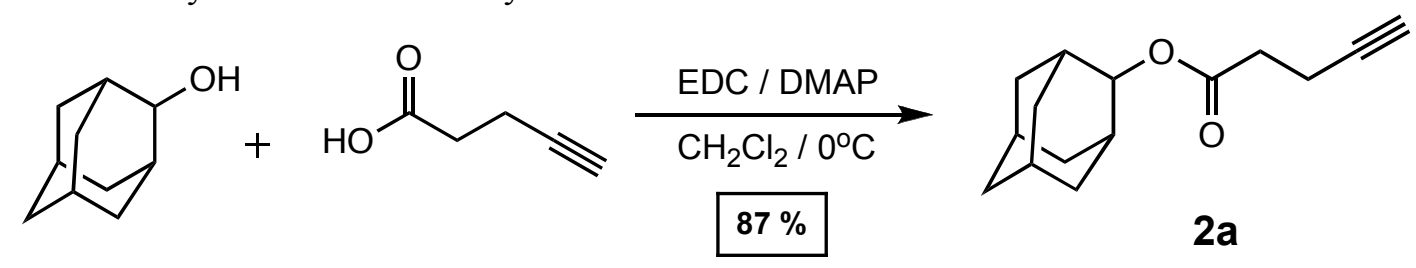

(2-Adamantanyl)-4-pentynoic Acid Ester (2a): A solution of pentynoic acid (2.5 g, $25.5 \mathrm{mmol})$ and 1-ethyl-3-(3-dimethylaminopropyl)-carbodiimide (EDC) $(6.54 \mathrm{~g}, 34 \mathrm{mmol})$ in $\mathrm{CH}_{2} \mathrm{Cl}_{2}(76$ $\mathrm{mL}$ ) was cooled down to $0^{\circ} \mathrm{C}$ before adding a solution of 2-adamantanol $(2.59 \mathrm{~g}, 17 \mathrm{mmol})$ in $\mathrm{CH}_{2} \mathrm{Cl}_{2}(100 \mathrm{~mL})$. The reaction was then warmed up to $\mathrm{RT}$ and stirred for $2 \mathrm{~h}$ before the addition of 4-methyldiaminopyridine (DMAP) (200 mg, $1.65 \mathrm{mmol}$ ). After stirring for $24 \mathrm{~h}$, the reaction 
was poured into $\mathrm{H}_{2} \mathrm{O}(100 \mathrm{~mL})$ and washed with $\mathrm{CH}_{2} \mathrm{Cl}_{2}(3 \times 50 \mathrm{~mL})$. The organic layer was washed with $\mathrm{H}_{2} \mathrm{O}(3 \times 50 \mathrm{~mL}), \mathrm{NaHCO}_{3}(2 \mathrm{M}, 30 \mathrm{~mL})$ and brine $(30 \mathrm{~mL})$. Chromatography $\left(\mathrm{SiO}_{2}\right.$, 1:2 EtOAc : Hexanes eluent) provided $2 \mathbf{a}$ as a white crystalline solid (3.45 g, 87 \%), mp 60.5$62.0{ }^{\circ} \mathrm{C} .{ }^{1} \mathrm{H}$ NMR $\left(500 \mathrm{MHz}, \mathrm{CDCl}_{3}, 25{ }^{\circ} \mathrm{C}\right): \mathrm{d}=4.94(\mathrm{t}, \mathrm{J}=3 \mathrm{~Hz}, 1 \mathrm{H}), 2.59-2.53(\mathrm{~m}, 2 \mathrm{H}), 2.53-$ $2.48(\mathrm{~m}, 2 \mathrm{H}), 2.05-1.90(\mathrm{~m}, 5 \mathrm{H}), 1.86-1.78(\mathrm{~m}, 4 \mathrm{H}), 1.78-1.67(\mathrm{~m}, 4 \mathrm{H}), 1.57-1.50(\mathrm{~m}, 2 \mathrm{H}) ;{ }^{13} \mathrm{C}$ NMR (125 MHz, $\left.\mathrm{CDCl}_{3}, 25{ }^{\circ} \mathrm{C}\right): 171.0,82.6,77.5,69.0,37.4,36.3,33.9,31.9,31.8,27.2,27.0$, 14.6. HRMS (FAB): Calcd for $\mathrm{C}_{15} \mathrm{H}_{20} \mathrm{O}_{2} \mathrm{~m} / z=232.1463$. Found $m / z=232.1468$.

Scheme S3. Synthesis of Adamantyl-Amide Derivative 2b.

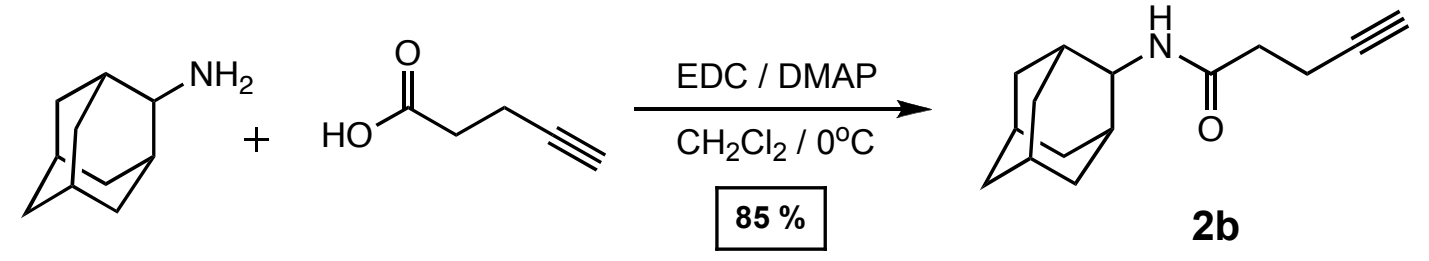

(2-Adamantanyl)-4-pentynoic Acid Amide (2b): A solution of pentynoic acid (0.981 g, 10 mmol) and 1-ethyl-3-(3-dimethylaminopropyl)-carbodiimide (EDC) $(2.5 \mathrm{~g}, 13 \mathrm{mmol})$ in $\mathrm{CH}_{2} \mathrm{Cl}_{2}$ $(30 \mathrm{~mL})$ was cooled down to $0^{\circ} \mathrm{C}$ before adding a solution of 2-adamantylamine $(1 \mathrm{~g}, 6.6 \mathrm{mmol})$ in $\mathrm{CH}_{2} \mathrm{Cl}_{2}(30 \mathrm{~mL})$. The reaction was then warmed up to $\mathrm{RT}$ and stirred for $2 \mathrm{~h}$ before the addition of 4-methyldiaminopyridine (DMAP) $(100 \mathrm{mg}, 0.825 \mathrm{mmol})$. After stirring for $24 \mathrm{~h}$, the reaction was poured into $\mathrm{H}_{2} \mathrm{O}(50 \mathrm{~mL})$ and washed with $\mathrm{CH}_{2} \mathrm{Cl}_{2}(3 \times 30 \mathrm{~mL})$. The organic layer was washed with $\mathrm{H}_{2} \mathrm{O}(3 \times 20 \mathrm{~mL}), \mathrm{NaHCO}_{3}(2 \mathrm{M}, 20 \mathrm{~mL})$ and brine $(20 \mathrm{~mL})$. Chromatography $\left(\mathrm{SiO}_{2}: 1: 2 \mathrm{EtOAc} / \mathrm{Hex}\right.$ eluent) provided $\mathbf{2 b}$ as a white crystalline solid $(1.3 \mathrm{~g}, 85 \%), \mathrm{mp} 126-$ $128.5^{\circ} \mathrm{C} .{ }^{1} \mathrm{H}$ NMR $\left(500 \mathrm{MHz}, \mathrm{CDCl}_{3}, 25^{\circ} \mathrm{C}\right): \mathrm{d}=6.02(\mathrm{~s}, 1 \mathrm{H}), 4.06(\mathrm{dt}, 8 \mathrm{~Hz}, 4 \mathrm{~Hz}, 1 \mathrm{H}), 2.55-$ $2.49(\mathrm{~m}, 2 \mathrm{H}), 2.43-2.37(\mathrm{~m}, 2 \mathrm{H}), 2.01(\mathrm{t}, 4 \mathrm{~Hz}, 1 \mathrm{H}), 1.94-1.59(\mathrm{~m}, 14 \mathrm{H}) ;{ }^{13} \mathrm{C}$ NMR $(125 \mathrm{MHz}$, $\left.\mathrm{CDCl}_{3}, 25{ }^{\circ} \mathrm{C}\right): 170.0,83.5,69.7,53.6,37.7,37.3,35.9,32.2,32.1,27.4,27.3,15.4$. HRMS (FAB): Calcd for $\mathrm{C}_{15} \mathrm{H}_{21} \mathrm{NO} m / z=231.1623$. Found $m / z=231.1629$.

Preparation of Amine Modified Porous MCM-41 Silica Particles: Synthesis of mesostructured silica nanoparticles was performed using a one-pot sol consisting of a tetraethylorthosilicate (TEOS) silica precursor and cetyltrimethyl-ammonium bromide (CTAB) surfactant in aqueous solution ${ }^{\mathrm{S} 3}$ at $80{ }^{\circ} \mathrm{C}$. The synthesized nanoparticles were collected by filtration and washed extensively with $\mathrm{MeOH}$ and distilled $\mathrm{H}_{2} \mathrm{O}$. The CTAB surfactant was removed by calcination in air at $550^{\circ} \mathrm{C}$ for $5 \mathrm{~h}$. The surfactant-free particles were then suspended in a solution of 3-aminopropyltriethoxysilane (APTES) in dry PhMe (10 mM) and heated under reflux for $12 \mathrm{~h}$ under $\mathrm{N}_{2}$. The amine-modified nanoparticles were collected by filtration, washed with dry PhMe, and dried under vacuum.

General Preparation of the MCM-41 Snap-Top System: A mixture of azide-functionalized nanoparticles $(100 \mathrm{mg})$, Rhodamine B (10 mg, $0.023 \mathrm{mmol})$ and $\alpha-C D(480 \mathrm{mg}, 0.493 \mathrm{mmol})$ were suspended in a 50:50 mixture of DMF and $\mathrm{H}_{2} \mathrm{O}(20 \mathrm{~mL})$ and stirred for $24 \mathrm{~h}$ at $5^{\circ} \mathrm{C}$. A solution of $\mathbf{2 a}$ or $\mathbf{2 b}$ in DMF ( $5 \mathrm{~mL}, 39 \mathrm{mM}$ ) was added, followed by the addition of $\mathrm{CuSO}_{4} \cdot 5 \mathrm{H}_{2} \mathrm{O}$ $(1.5 \mathrm{mg}, 0.0098 \mathrm{mmol})$ and ascorbic acid $(4 \mathrm{mg}, 0.019 \mathrm{mmol})$. The mixture was stirred at $5^{\circ} \mathrm{C}$ for $3 \mathrm{~d}$. The nanoparticles were then filtered and washed thoroughly with $\mathrm{MeOH}$ and $\mathrm{H}_{2} \mathrm{O}$ to remove unreacted and adsorbed molecules. The resulting red nanoparticles were finally dried under high vacuum.

General Procedure for Enzymatic Activation of the Snap-Top System. A sample of Rhodamine B loaded red nanoparticles $(10 \mathrm{mg})$ was placed in the corner of a $15 \mathrm{~mL}$ quartz 
cuvette and then filled with a HEPES buffer solution $(12 \mathrm{~mL}, 50 \mathrm{mM}, \mathrm{pH}=7.5)$. A sample of a PLE solution $\left[0.12 \mathrm{~mL}, 10 \mathrm{mg} / \mathrm{mL}\right.$ solution in $\left.3.2 \mathrm{M}\left(\mathrm{NH}_{4}\right)_{2} \mathrm{SO}_{4}\right]$ was then added to the cuvette and the emission spectra of the solution (excitation at $580 \mathrm{~nm}$ ) was monitored over a period of 40 min.

\section{Dynamic Light Scattering}

Dynamic light scattering was performed on a Beckman Coulter N4 Plus particle sizer, with a 633 $\mathrm{nm} \mathrm{HeNe}$ excitation source. The measurements were carried out in $\mathrm{MeOH}$ on calcined nanoparticles prior to any surface modifications.

Table. Average Diameters of Calcined Mesoporous Silica Nanoparticles from DLS Measurements.

\begin{tabular}{|c|c|c|}
\hline & Particle radius (nm) & Standard Deviation (nm) \\
\hline Run 1 & 415 & 175 \\
\hline Run 2 & 407 & 65 \\
\hline Run 3 & 411 & 150 \\
\hline Average & $\mathbf{4 1 1}$ & $\mathbf{1 3 0}$ \\
\hline
\end{tabular}

\section{X-Ray Diffraction}

Powder X-ray diffraction measurements were carried out using a Panalytical X'Pert Pro powder diffractometer. The radiation source is copper $\left(K_{\alpha 1}\right.$ and $\left.K_{\alpha 2}=1.5418 \AA\right)$

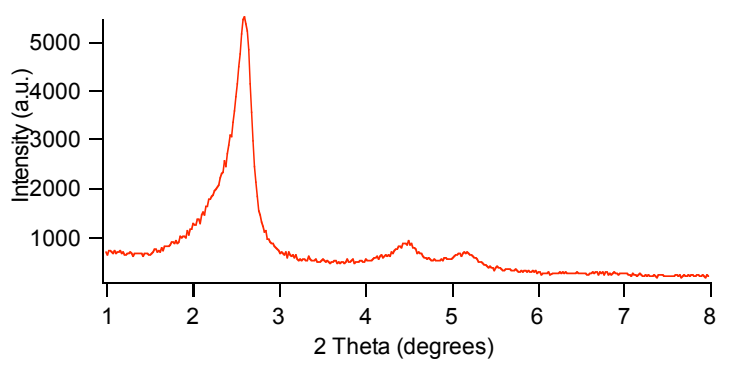

Supporting Figure 1. XRD pattern of calcined mesostructured silica nanoparticles. The 100 peak at $2 \theta=2.6^{\circ}$ corresponds to a $2 \mathrm{D}$-hexagonal mesostructure with lattice spacing of $3.4 \mathrm{~nm}$.

\section{Scanning Electron Microscopy}

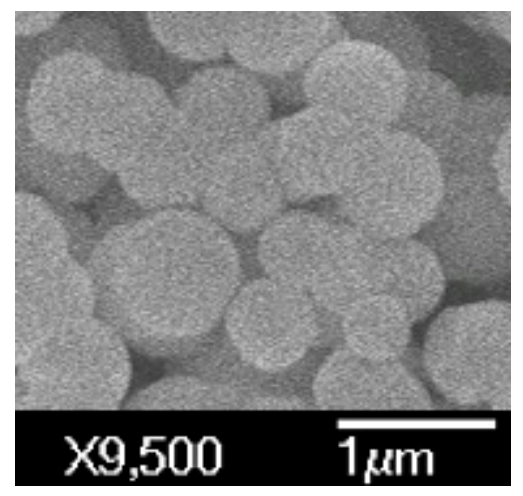

Supporting Figure 2. SEM image of calcined mesostructured amine-modified silica nanoparticles. 


\section{FT Infrared Spectroscopy}

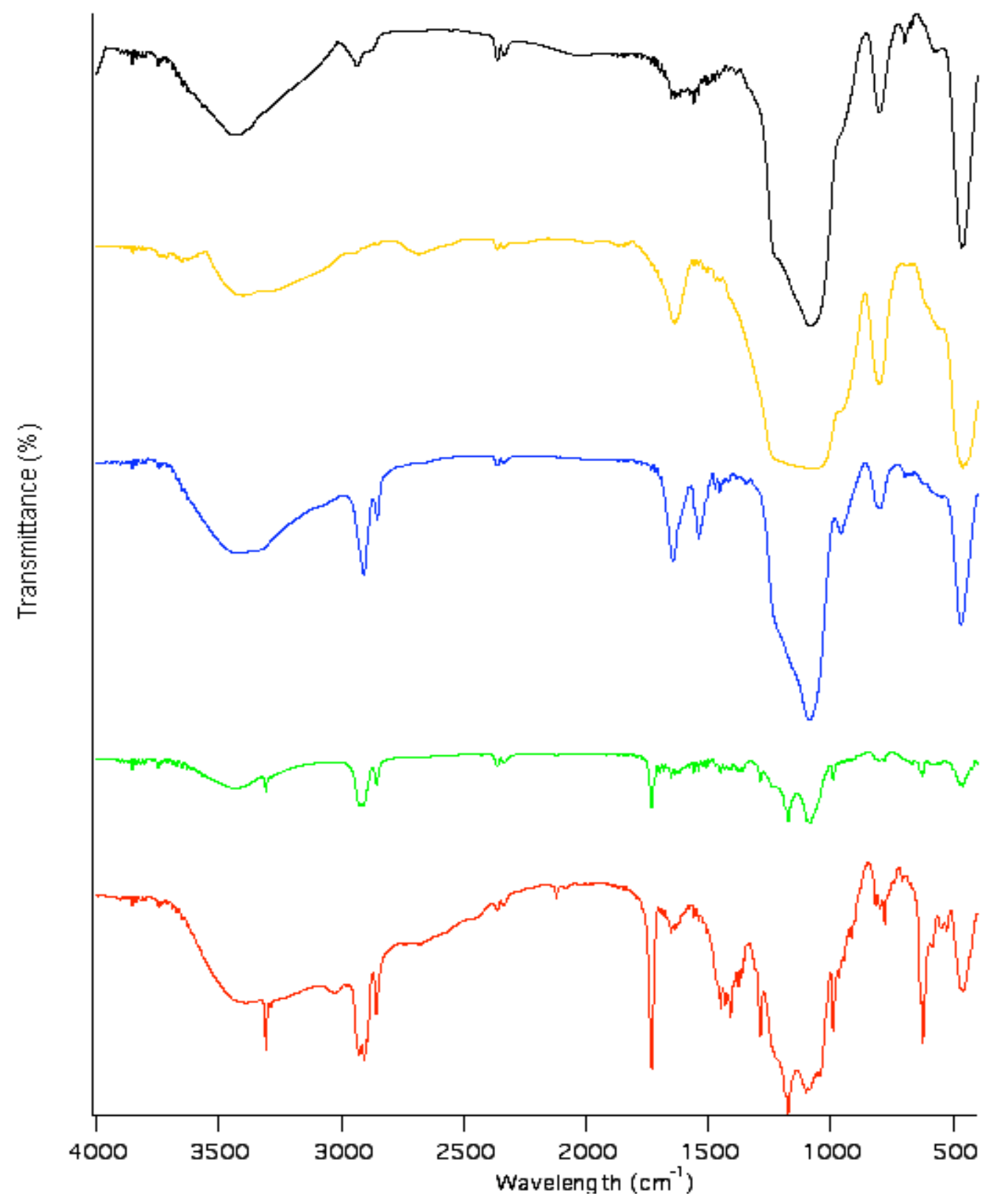

Supporting Figure 3. FTIR spectra of amine particles (black), azide particles (orange), amidecapped particles (blue), ester-capped particles (green) and released ester-capped particles (red) 


\section{Time-Dependent Release Profile}

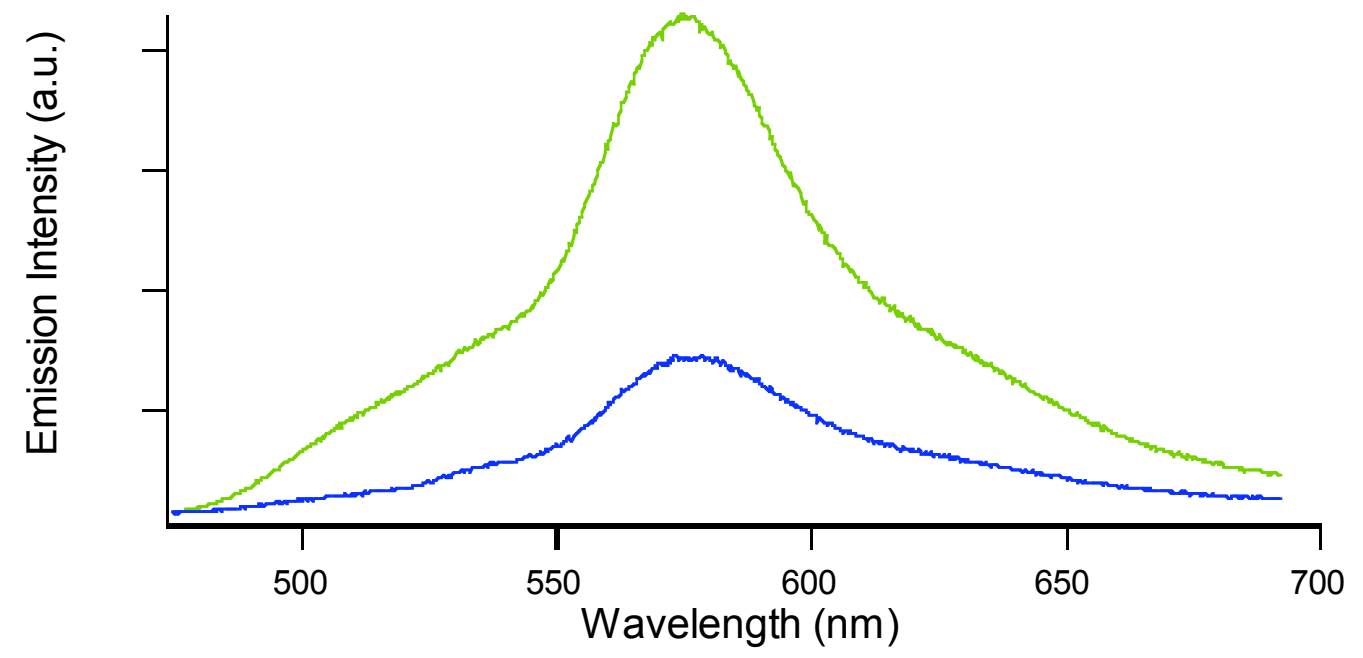

Supporting Figure 4. The emission intensity of Rhodamine B released into solution 100 seconds (blue) and 1000 seconds after addition of esterase.

\section{Absorption Spectra}

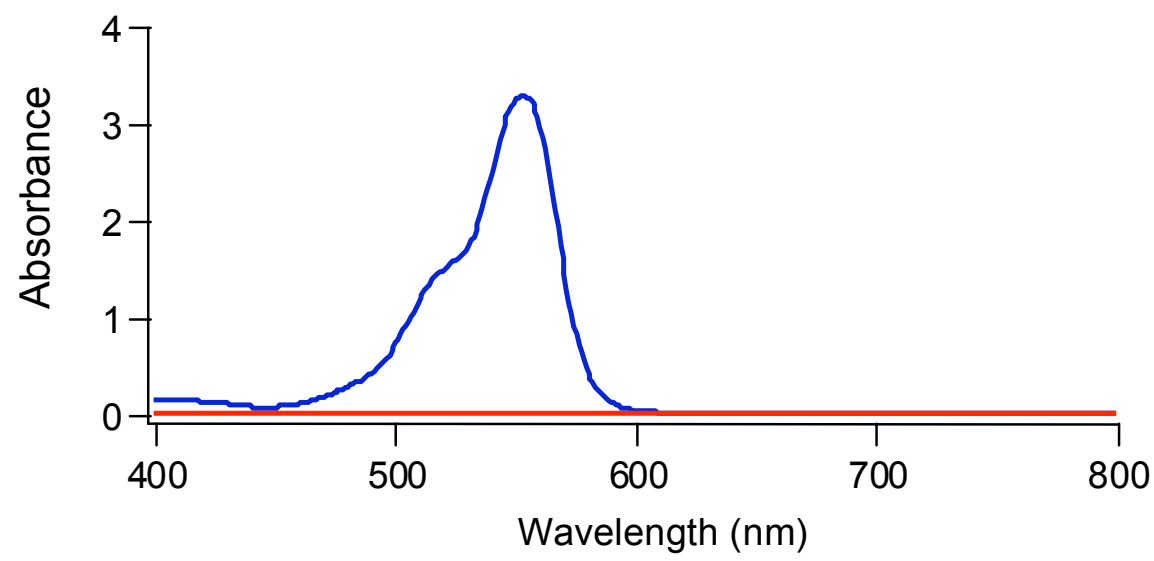

Supporting Figure 5. The absorption spectrum of Rhodamine B in the solution above the particles before (red) and after (blue) esterase-triggered release.

\section{References}

(S1) Fernandez-Megia, E.; Correa, J.; Rodriguez-Meizoso, I.; Riguera, R. Macromolecules 2006, 39, 2113.

(S2) Meunier, S. J.; Wu, Q.; Wang, S.-N.; Roy, R. Can. J. Chem. 1997, 75, 1472.

(S3) Huh, S.; Wiench, J. W.; Yoo, J. C.; Pruski, M.; Lin, V. S. Y. Chem. Mater. 2003, 15, 4247. 